\title{
Both external and internal factors as an explanation of depopulation of cities on the
}

\author{
area of Poland
}

\author{
Iwona Kantor-Pietraga
}

Department of Economic Geography, Faculty of Earth Sciences, University of Silesia, Będzińska Str. 60, 41-200 Sosnowiec, Poland E-mail address: kantor.pietraga@interia.pl

\begin{abstract}
The aim of this paper is an attempt of explanation basic factors of depopulation in case of cities in Poland in the $20^{\text {st }}$ and in the beginning of $21^{\text {st }}$ century. Author takes into consideration only large urban centers with population more than 50 thousands inhabitants. Population changes are described according to historical periods: 1900-1946 (including World War II), postwar period (1946-1989) and period socio-economic and political changes in Poland (1990-2010). A key question is basic thesis that different determinants of depopulation have two sources: internal as well as external ones. Some of them arise only in defined periods and social-economic conditions. The most important have been underlined in this paper. It has been highlighted that is visible different between simply depopulation of cities as consequence of military operations, for example and contemporary urban shrinkage as an effect of compound social-economic background. Paper gives some reflections on different possibilities for defense of cities not only against consequences of the second demographic transition but also functional changes, especially in case of larger post-industrial centers. Important question that have been underlined in paper is problem of urban shrinkage as contemporary dimension of depopulation. Presented information clearly shows that in demographic terms process of contemporary shrinkage is comparable with urban demographic decline of the WW2 period.
\end{abstract}

KEY WORDS: depopulation, urban shrinkage, population decline, large cities

\section{Introduction}

The problem of city depopulation is one of the most crucial issues in studying population geography. Population decrease is not a phenomena that refers to a selected group of cities only, or to a specific period of one hundred years (MYKHNENKO \& TUROK, 2008). Population decrease in cities, both at present and in the past, has been experienced by various types of cities of different size, function or geographical location.

This remark applies in the case of the territory of Poland as well. A broader examination of the demographic development of Polish cities in its dynamic apprehension, including their depopulation, was recently described by GAWRYSZEWSKI (2005). On the regional level, and in reference to the Silesian voivodeship area, elaborations by JELONEK (1956, 1967), DŁUGOSZ (2005), KUREK (2005), KANTORPietraga \& KRZYSZTOFIK (2009) or KRZYSZTOFIK
ET AL. (2011), KANTOR-Pietraga (2014), need to be mentioned.

In studies, especially on the long-term decrease of population, next to the establishment of trajectories for the phenomena, a basic element shall be the explanation of the process. The conditionings for depopulation are varied. On the national level, which refers to many cities, and often to their networks, it seems justified to take into account a basic division of external and internal factors.

The external factors shall be understood as a totality of phenomena and processes, whose origin is placed outside the borders - in this case - of the country, and whose direct interaction has some influence on the population of a single city or a group of cities. The most well-known factor of this type are military operations performed on the area of a given country, with the engagement of at least one foreign country. In other cases, war and armed operations may be an internal factor, 
as long as the conflict is waged within the borders of one country and with the engagement of its inhabitants only.

However, the most frequent internal factor that influences the destabilization of demographic growth of cities are economic or socio-economic fluctuations. They may obviously have their indirect origin beyond the borders of a given country, but in the direct meaning, they shall be perceived primarily as an internal factor.

Both factors were present on the territory of contemporary Poland in the 20th century and both have had an effect on the networks of all larger cities. It is worth highlighting, still in the introduction, that the territory of Poland does not posses a single large city, which has not experienced the phenomena of depopulation, at least in one of the distinguished research periods, referring to the $20^{\text {th }}$ century and the beginning of the $21^{\text {st }}$ century.

The research subject in this elaboration consists of a group of 55 cities within the borders of Poland between 1900 and 2010 (Fig. 1). The definition of cities reveals that they are places populated by at least 50 thousand people before 1945 and at least 100 thousand after World War II. Each city, which fulfilled at least one of the two criteria presented above, was classified to the group of researched centres.

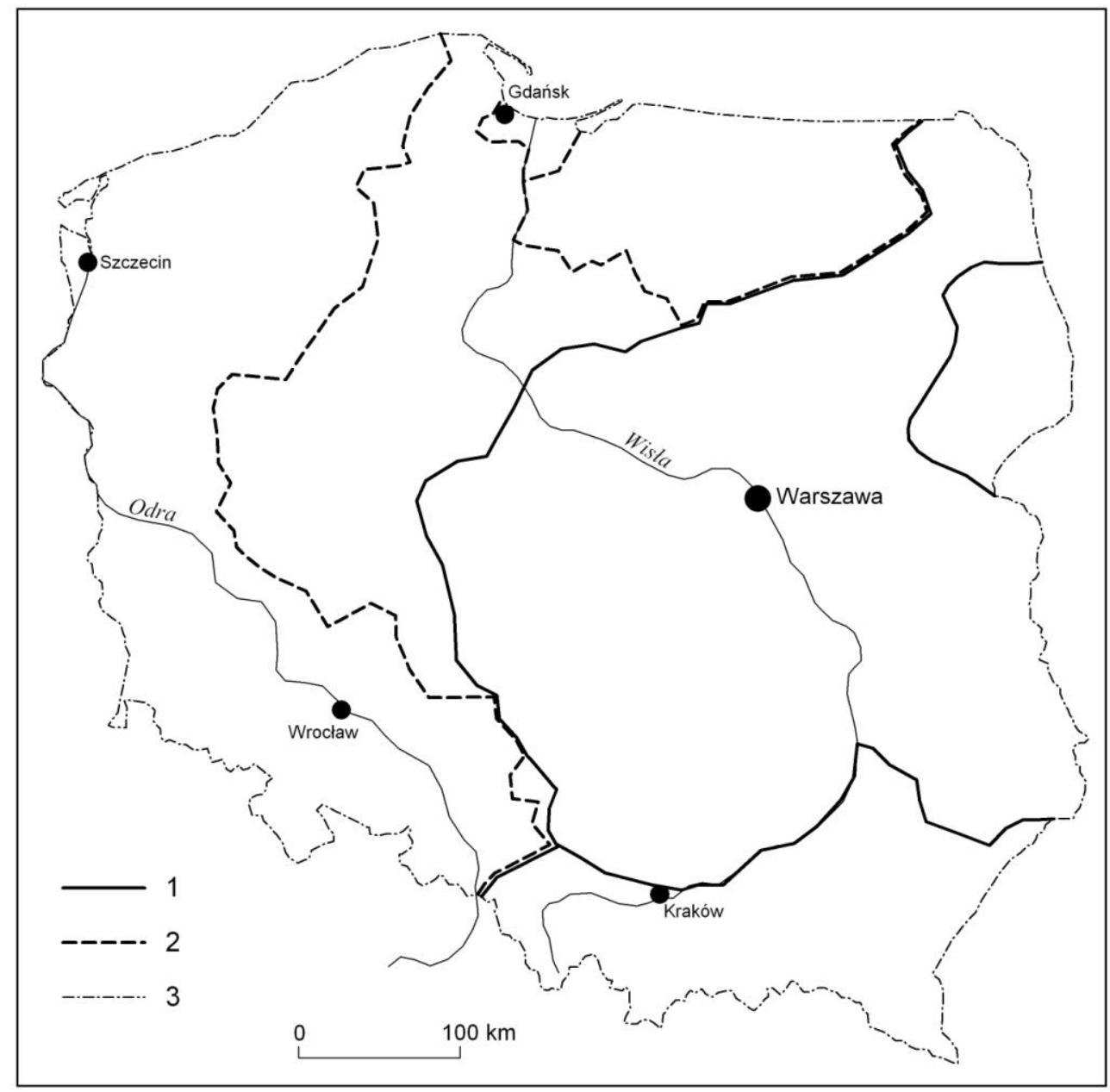

Fig. 1. Changeability of political borders on the area of contemporary Poland in the $19^{\text {th }}$ and $20^{\text {th }}$ century 1 - borders of countries in the period 1810-1914, 2 - borders of Poland in the period 1923-1939, 3 - contemporary borders of Poland (source: by author on the base of: Historical Atlas of World, 1986)

\section{Depopulation of large cities in the first half of the $20^{\text {th }}$ century $(1900-1946)$}

For most cities in Poland, the turn of the $19^{\text {th }}$ and $20^{\text {th }}$ centuries primarily constituted a period of dynamic development. This remark mostly refers to medium-sized towns (20-50 thousand inhabitants) and large cities - over 50 thousand inhabitants. In the group of small and very small cities, development factors were strongly dependent on the type of economic basis of the town. Generally, a noticeable trend for demographic development was to concentrate in towns with strongly visible specialized functions, based on industry, mining, rail transport or spa and holiday functions. Centres with local functions (central for the lower rank) developed poorly. In the second half of the $19^{\text {th }}$ century, nearly 400 of them 
were deprived of their municipal rights. It is stressed, however, that in the case of many of them, the decision was irrational (in revenge for the participation of Polish people in the January Uprising), and it shall be pointed out that a majority of them became strongly agricultural.

The demographic development of cities in the beginning of the $19^{\text {th }}$ and $20^{\text {th }}$ centuries was primarily decided upon by specialized, mostly industrial functions. This trend prevailed practically until the end of the $20^{\text {th }}$ century. It applied to cities as well. In this case, many of them held important central functions at various hierarchy levels. On the basis of data presented in Table 1 and also Table 2, it shall be stated that the periods of political and economic stability (1900-1910 and 1921-1939) resulted in a steady and regular population growth in cities located presently on the territory of Poland and at the time on the territory of three, or after World War I, two different countries. The fact that population growth in the stated time frames was noted by all analysed cities reveals the absolute role of the economic factor as the stabilizer of development in this part of Central and Eastern Europe.

This natural process of development, driven by specialized functions and reinforced with the role of cities as regional or supralocal centres was, however, destabilized by the two successive world wars. During World War I, population drops referred only to some of the analyzed cities. Comparatively, the largest population losses happened in cities located in the area of the former Russian and Austrian annexations. An exception was made by cities with regional functions - the seats of the former: Lublin, Kielce and Radom provinces and also Krakow, which was located in the Austro-Hungarian Galicia. Other cities, even if they did not observe population decrease, they experienced a rather insignificant increase, frequently at the verge of statistical significance. Not always was the population decrease a direct result of war operations. The reason for depopulation was often the disappearance of the hitherto prevailing border of the country (or sometimes the emergence of it). This may be linked to the population loss in the border cities of Będzin or Bytom (until 1914).

But it was World War II that lead to a widespread depopulation of cities located in the area of contemporary Poland. In the period 1939-1946, only 3 out of 55 cities (mining and industrial: Chorzów and Wałbrzych and multi-functional supraregional centre - Poznań) observed population increase. The others became depopulated to a large extent (see Fig. 2).

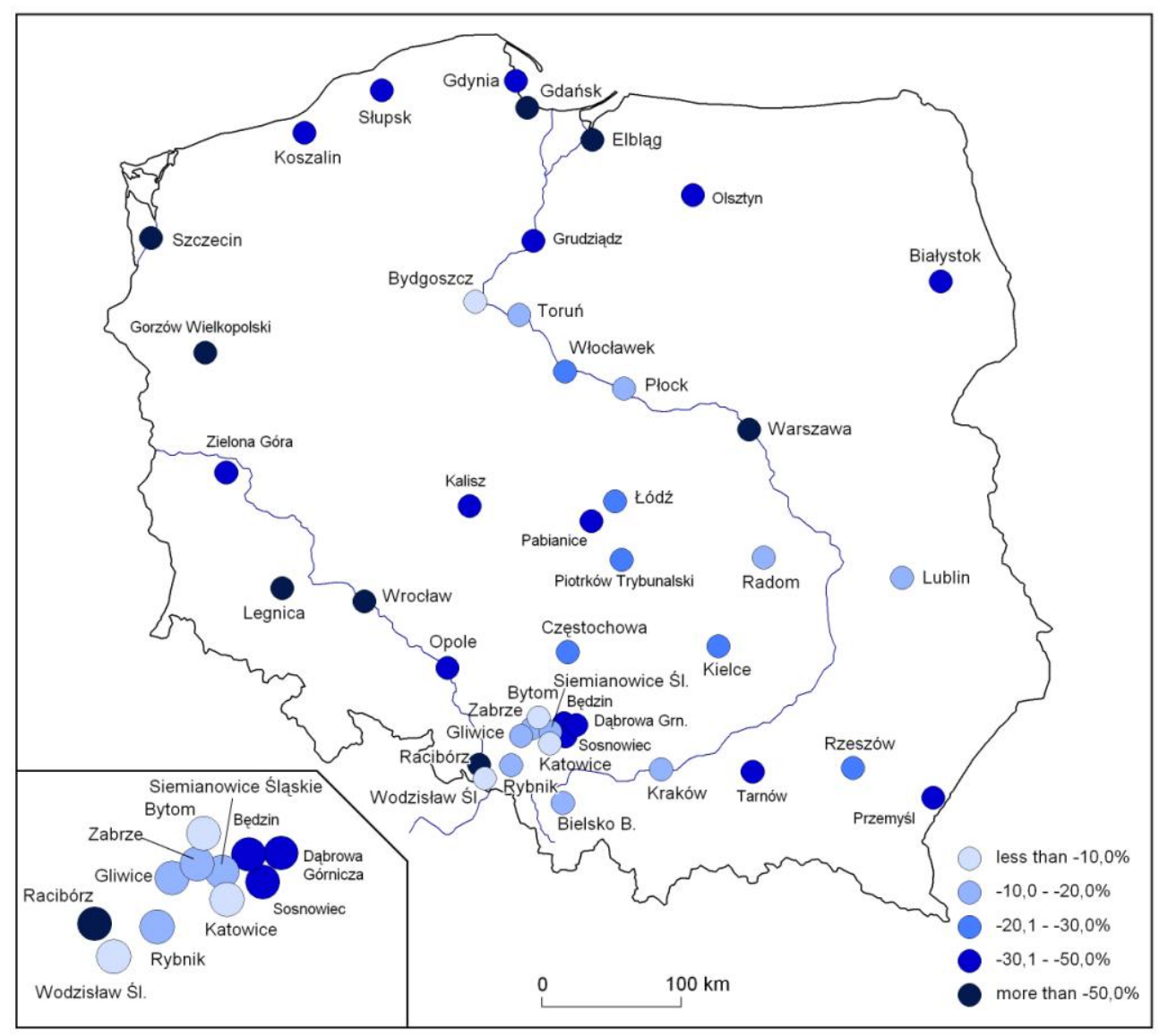

Fig. 2. Depopulation of large cities (more than 50000 inhabitants) on the contemporary area of Poland, 1939-1946 
Table 1. Population changes in studied cities of Poland

(source: by author on the base of Jelonek, 1956, 1967; Powierzchnia i ludność..., 1990, 2010)

\begin{tabular}{|c|c|c|c|c|}
\hline Cities & $1897 / 1900$ & 1946 & 1990 & 2010 \\
\hline Będzin & 23757 & 27754 & 76222 & 58706 \\
\hline Białystok & 66032 & 56759 & 270568 & 294685 \\
\hline Bielsko-Biała* & • & - & 181278 & 175402 \\
\hline Bydgoszcz & 52204 & 134614 & 381534 & 357650 \\
\hline Bytom & 51404 & 93179 & 231206 & 182749 \\
\hline Chorzów & 57919 & 110675 & 131902 & 113007 \\
\hline Częstochowa & 45045 & 101255 & 257957 & 239319 \\
\hline Dąbrowa Górnicza & - & 28070 & 136862 & 127686 \\
\hline Elbląg & 52518 & 20924 & 126056 & 126419 \\
\hline Gdańsk & 140563 & 117894 & 465143 & 456591 \\
\hline Gdynia & $\bullet$ & 77829 & 251498 & 247859 \\
\hline Gliwice & 52362 & 95980 & 214202 & 196167 \\
\hline Gorzów Wielkopolski & 33598 & 19796 & 124285 & 125383 \\
\hline Grudziądz & 32727 & 36805 & 102303 & 99074 \\
\hline Jastrzębie-Zdrój & $\bullet$ & $\bullet$ & 103734 & 92988 \\
\hline Kalisz & 24418 & 48092 & 106151 & 107019 \\
\hline Katowice & 31738 & 128290 & 366798 & 308548 \\
\hline Kielce & 23178 & 49960 & 214202 & 204835 \\
\hline Koszalin & 20417 & 17115 & 108697 & 107986 \\
\hline Kraków & 91323 & 229396 & 750540 & 755000 \\
\hline Legnica & 54882 & 24357 & 105216 & 104178 \\
\hline Lublin & 50385 & 99400 & 351353 & 349440 \\
\hline Łódź & 314020 & 496929 & 848258 & 742387 \\
\hline Olsztyn & 24295 & 29053 & 162935 & 176457 \\
\hline Opole & 30112 & 27666 & 128429 & 125792 \\
\hline Pabianice & 26765 & 34140 & 75247 & 69018 \\
\hline Piotrków Trybunalski & 31182 & 40141 & 80977 & 77810 \\
\hline Płock & 26966 & 28508 & 123398 & 126542 \\
\hline Poznań & 117033 & 267978 & 590101 & 554221 \\
\hline Przemyśl & 46295 & 36841 & 68524 & 66549 \\
\hline Racibórz & 25250 & 19605 & 64394 & 56484 \\
\hline Radom & 29896 & 69455 & 228487 & 223397 \\
\hline Ruda Śląska & $\bullet$ & $\bullet$ & 171034 & 143394 \\
\hline Rybnik & 7221 & 23052 & 143980 & 141372 \\
\hline Rzeszów & 15010 & 29407 & 153041 & 177521 \\
\hline Siemianowice Śląskie & $\bullet$ & 32708 & 81123 & 70712 \\
\hline Słupsk & 27293 & 33948 & 101237 & 97087 \\
\hline Sosnowiec & $\bullet$ & 77853 & 259353 & 219300 \\
\hline Szczecin & 210702 & 72948 & 413437 & 406307 \\
\hline Świętochłowice & $\bullet$ & - & 60504 & 54091 \\
\hline Tarnów & 31691 & 33108 & 121216 & 115158 \\
\hline Toruń & 29635 & 68085 & 202218 & 205718 \\
\hline Tychy & - & - & 191723 & 129449 \\
\hline Wałbrzych & 15105 & 72976 & 141011 & 121363 \\
\hline Warszawa & 683692 & 478755 & 1655661 & 1714446 \\
\hline Włocławek & 22907 & 48126 & 122144 & 117402 \\
\hline Wodzisław Śląski & 2701 & 5110 & 111741 & 49033 \\
\hline Wrocław & 422709 & 170656 & 643218 & 632146 \\
\hline Zabrze & - & 104184 & 205029 & 187674 \\
\hline Zielona Góra & 20983 & 15738 & 114126 & 117503 \\
\hline
\end{tabular}

*- Bielsko and Biała were separately towns until 1939 and 1945-1951 
Table 2. Dynamics of population in studied cities of Poland (in \%)

\begin{tabular}{|c|c|c|c|}
\hline Cities & $1897 / 1900-1946$ & $1946-1990$ & $1990-2010$ \\
\hline Będzin & 16.8 & 174.6 & -23.0 \\
\hline Białystok & -14.0 & 376.7 & 8.9 \\
\hline Bielsko-Biała & $\bullet$ & $\bullet$ & -3.2 \\
\hline Bydgoszcz & 157.9 & 183.4 & -6.3 \\
\hline Bytom & 81.3 & 148.1 & -21.0 \\
\hline Chorzów & 91.1 & 19.2 & -14.3 \\
\hline Częstochowa & 124.8 & 154.8 & -7.2 \\
\hline Dąbrowa Górnicza & $\bullet$ & 387.6 & -6.7 \\
\hline Elbląg & -60.2 & 502.4 & 0.3 \\
\hline Gdańsk & -16.1 & 294.5 & -1.8 \\
\hline Gdynia & - & 223.1 & -1.4 \\
\hline Gliwice & 83.3 & 123.2 & -8.4 \\
\hline Gorzów Wielkopolski & -41.1 & 527.8 & 0.9 \\
\hline Grudziądz & 12,5 & 178.0 & -3.2 \\
\hline Jastrzębie-Zdrój & $\bullet$ & $\bullet$ & -10.4 \\
\hline Kalisz & 97.0 & 120.7 & 0.8 \\
\hline Katowice & 304.2 & 185.9 & -15.9 \\
\hline Kielce & 115.5 & 328.7 & -4.4 \\
\hline Koszalin & -16.2 & 535.1 & -0.7 \\
\hline Kraków & 151.2 & 227.2 & 0.6 \\
\hline Legnica & -55.6 & 332.0 & -1.0 \\
\hline Lublin & 97.3 & 253.5 & -0.5 \\
\hline Łódź & 58.2 & 70.7 & -12.5 \\
\hline Olsztyn & 19.6 & 460.8 & 8.3 \\
\hline Opole & -8.1 & 364.2 & -2.1 \\
\hline Pabianice & 27.6 & 120.4 & -8.3 \\
\hline Piotrków Trybunalski & 28.7 & 101.7 & -3.9 \\
\hline Płock & 5.7 & 332.9 & 2.5 \\
\hline Poznań & 129.0 & 120.2 & -6.1 \\
\hline Przemyśl & -20.4 & 86.0 & -2.9 \\
\hline Racibórz & -22.4 & 228.5 & -12.3 \\
\hline Radom & 132.3 & 229.0 & -2.2 \\
\hline Ruda Śląska & - & $\bullet$ & -16.2 \\
\hline Rybnik & 219.2 & 524.6 & -1.8 \\
\hline Rzeszów & 95.9 & 420.4 & 16.0 \\
\hline Siemianowice Śląskie & $\bullet$ & 148.0 & -12.8 \\
\hline Słupsk & 24.4 & 198.2 & -4.1 \\
\hline Sosnowiec & $\bullet$ & 233.1 & -15.4 \\
\hline Szczecin & -65.4 & 466.8 & -1.7 \\
\hline Świętochłowice & $\bullet$ & $\bullet$ & -10.6 \\
\hline Tarnów & 4.5 & 266.1 & -5.0 \\
\hline Toruń & 129.7 & 197.0 & 1.7 \\
\hline Tychy & $\bullet$ & - & -32.5 \\
\hline Wałbrzych & 383.1 & 93.2 & -13.9 \\
\hline Warszawa & -30.0 & 245.8 & 3.6 \\
\hline Włocławek & 110.1 & 153.8 & -3.9 \\
\hline Wodzisław Śląski & 89.2 & 2086.7 & -56.1 \\
\hline Wrocław & -59.6 & 276.9 & -1.7 \\
\hline Zabrze & $\bullet$ & 96.8 & -8.5 \\
\hline Zielona Góra & -25.0 & 625.2 & 3.0 \\
\hline
\end{tabular}


An analogous case happened with reference to all cities in Poland. According to GAWRYSZEWSKI (2005), out of 682 towns and cities present in both 1939 and 1945, and presently located on the territory of Poland, only 45 cities or towns observed population increase.

The cities located in the territory of Germany, until 1945 became the most depopulated. At that time, Szczecin lost $81 \%$ of its inhabitants, Elbląg $75.6 \%$, Wrocław $-72.9 \%$, and Legnica $70.9 \%$. Among the cities that belonged to Poland before World War II, the most severe losses, not only in terms of population, were suffered by Warsaw (demographic decrease of over 62\%). Depopulation in all the cities mentioned above was connected with significant destruction of the urban fabric in these places. The centres of these cities turned into rubble for several or more than a dozen years. An important problem was also the eviction and migration of the German population. Even though in place of departing Germans came settlers from the central and eastern European area, and also from abroad, they were not able, for the longest time, to replenish the number of inhabitants from the period preceding the war.

In the case of Szczecin, an additional problem was posed by the dilemma of in which country the city should be situated. The uncertainty was temporized and limited the inflow of migrants, especially in 1945.

The analysis of the scale of depopulation in the cities of present Poland, right after World War II ended, leads to the statement that the most important conditions in the areas, which before 1939 belong to the II RP were the following:

1) losses in Jewish population - about $2,7 \mathrm{mln}$ inhabitants (GAWRYSZEWSKI, 2005; WYSIEDLENIA..., 2008),

2) losses in Polish population - about $2,8 \mathrm{mln}$ inhabitants (GAWRYSZEWSKI, 2005; WYSIEDLENIA..., 2008),

3) degradation of the urban fabric of cities, And in the areas, which belonged to Germany, respectively:

1) migration of the German population to inland Germany,

2) degradation of the urban fabric of cities,

3) losses of German population,

4) political uncertainty of the so called Regained Territories.

World War II also had its impact on the overall balance of the demographic development of cities in the first half of the $20^{\text {th }}$ century (1900-1945). Generally, an increase was noticed in the cities located on the territory of Poland before 1945. On the other hand, a decrease took place in areas, which were previously located in Germany (10 out of 16 here analysed). In many cases, the population of 1939 was only brought back after 20 years.

The period of the first half of the $20^{\text {th }}$ century, in the context of demographic development of the land of contemporary Poland shall be treated as a time frame, which was determined by:

1) the inner stability of economic and social processes within the frames of the free market economy, which leads to a population increase, as well as

2) the outer destabilization of the political, economic and social situation in the periods of world wars and their multiple-aspect consequences leading to a population decrease.

\section{Depopulation of analysed cities in 1945-1989}

The post-war period, lasting until the second to last decade of the $20^{\text {th }}$ century, primarily conditioned a dynamic increase of population in larger cities of Poland. All cities experienced an absolute population increase. The increase was of a varied scale, from just over a dozen percent (Chorzów) to even over 1000\% (Jastrzębie Zdrój). In fact, this period should be beyond the point of interest of this article. It is interesting, though, that this was the prelude to the phenomena and processes which emerged fully after 1990.

Then, a dual character of demographic development of Polish cities was revealed. It means that the cities serving regional or supraregional functions started showing a more balanced and harmonious population increase. The percentage of the increase was, as a rule, lower than in cities with a more strongly visible specialization, based mainly on industry and mining.

This group of centres may be divided into two types of cities. The first are developing cities, whose development has been based on industrial or mining activities for at least several dozen years. Spectacular population gains connected with the dynamic development of population happened mostly in the period of 1850-1950. In the post-war period, their development was limited by the scale of spatial investment and something that may be described as "the highest development limit of the local economic base." In this group, in some sub-periods of 10 years, some population decrease may be observed (Bytom, Chorzów, Zabrze). The group of discussed cites includes mainly cities located in the central and western part of the Katowice conurbation core, but also Wałbrzych or Łódź. Within the Katowice conurbation, this part of the urban complex was described by RUNGE as "the depopulation crater" 
(KRZYSZTOFIK ET AL., 2011, p. 11). It entailed the cities of Bytom, Chorzów, Siemianowice Śląskie, Ruda Śląska, Świętochłowice and Zabrze. Their development happened, but not until after 1990, and, however, the genesis shall be sought at least in the 1970s. Its characteristic feature, in ten-year intervals, was more and more frequent 1-digit demographic growth, with clear, two-digit increases both in neighbouring cities and in Poland, as a whole.

The other group of strongly specialized cities consisted of cities which were rapidly developed (Dąbrowa Górnicza, Sosnowiec) or the so called, 'new cities' (Jastrzębie Zdrój, Tychy). Their very dynamic demographic growth, especially in the 1970s, based on the impetuous development of mining and heavy industry, will be contrasted with the phenomenon of shrinkage or, in its narrow meaning - depopulation, in the following research period.

\section{Depopulation of analysed cities after political changes (1990-2010)}

The process of the slowing down of the growth of population in single large cities, which started in the 1970s and the 1980s, transformed into the stage of depopulation and shrinking of a larger number of urban centres in the 1990s.

On the national level, two basic factors of depopulation in large cities may be distinguished. The first one is the economic crisis connected with the economic, social and political transformation at the turn of the centuries. The other one is noticeable suburbanization, which is dynamically developing around the majority of large cities and urban agglomerations.

Both phenomena constitute elements of the broadly understood inner factor, conditioning the depopulation of cities. Even though the demographic shrinkage of cities is not a phenomenon that might be narrowed down spatially to Poland or Central and Eastern European countries only, it shall be stated that the direct causes of this phenomenon, almost always lie in the possibilities of development for a specific city and its infrastructure. It shall be noticed that not all large cities in contemporary Poland are depopulating. Even if it is the case, the same model may not always be applied. The depopulation model is mostly connected with the functional character and the location of a given city with regard to the regional and local settlement network. The degree of development of metropolitan functions and the level of economic development are extremely crucial as well.

Generally, in the settlement network of Poland, two types of depopulating centres are emerging the first type of suburbanization. In this case, the depopulation of a large city, which frequently functions as a core of urban agglomeration, is visible, with the simultaneous significant development of the suburban zone. The depopulation of the city happens at the expense of the surroundings, but it is still, relatively, the most mellow dimension of the demographic shrinking phenomenon $(\mathrm{COUCH}$ ET AL., 2012; KABISCH ET AL., 2012; HAASE ET AL., 2013; BERNT ET AL., 2014; KURCZENIE SIĘ MIAST..., 2014; RINK ET AL., 2014). The development of suburbia happens mostly in the closest proximity of the city, and with the possibility of its spatial and territorial expansion, there is a chance to "reclaim" the previously lost inhabitants. Moreover, the city that loses its inhabitants to the benefit of its closest neighbourhood, to a certain degree benefits from their presence in proximity. It is also important for the surroundings to develop, not only the city.

A more dramatic situation takes place in cities that are shrinking according to the second model. In this case, the suburbanization is of secondary, often marginal significance (the northern edges of the Katowice conurbation), while long-distance migrations are visible. Emigration, with the simultaneous ageing of the remaining population. This phenomena is almost always accompanied by the surplus of deaths over births. The city is loosely connected with its rural surroundings (Wałbrzych) or its access to it is limited (the core of the Katowice conurbation). Whereas in the case of the first type of depopulating cities, we shall talk about a partial, "apparent" depopulation or the creation of "core depopulation craters," in the other case we are dealing with actual depopulation, with a "demographic hollow," metaphorically speaking.

In the first case described, the decline in population is of a point character and refers mainly to the central district or selected block of flats districts of an older type. In the case of total depopulation, the drop in population refers to all or almost all parts of the city, regardless of their morphological or functional character. In Sosnowiec, for instance, in the period of 1988-2005, none of the 17 city districts recorded population increase (KRZYSZTOFIK ET AL., 2011, p.32). It is similar in almost all medium-sized and large cities or the above mentioned Katowice conurbation (KRZYSZTOFIK ET AL., 2014), see Fig. 3.

The first type of depopulation refers mainly to big and large cities, which develop relatively dynamically in terms of economy, finding new prospects for success after the transformation. These are, as a rule, centres which in the post-war period maintained fairly balanced proportions 
between the production sector and the services sector, with a strong rank in the regional settlement network (e.g. capitals of voivodeships). Their development is an effect of concentration of potential, frequently of the whole voivodeship, and a noticeable depopulation came as an effect of the local arrangement of multi-dimension growth effects. Some of these centres, such as Kraków or Rzeszów, even experience demographic growth, however, in the case of the latter, it is strongly connected with the administrative expansion of the city itself.

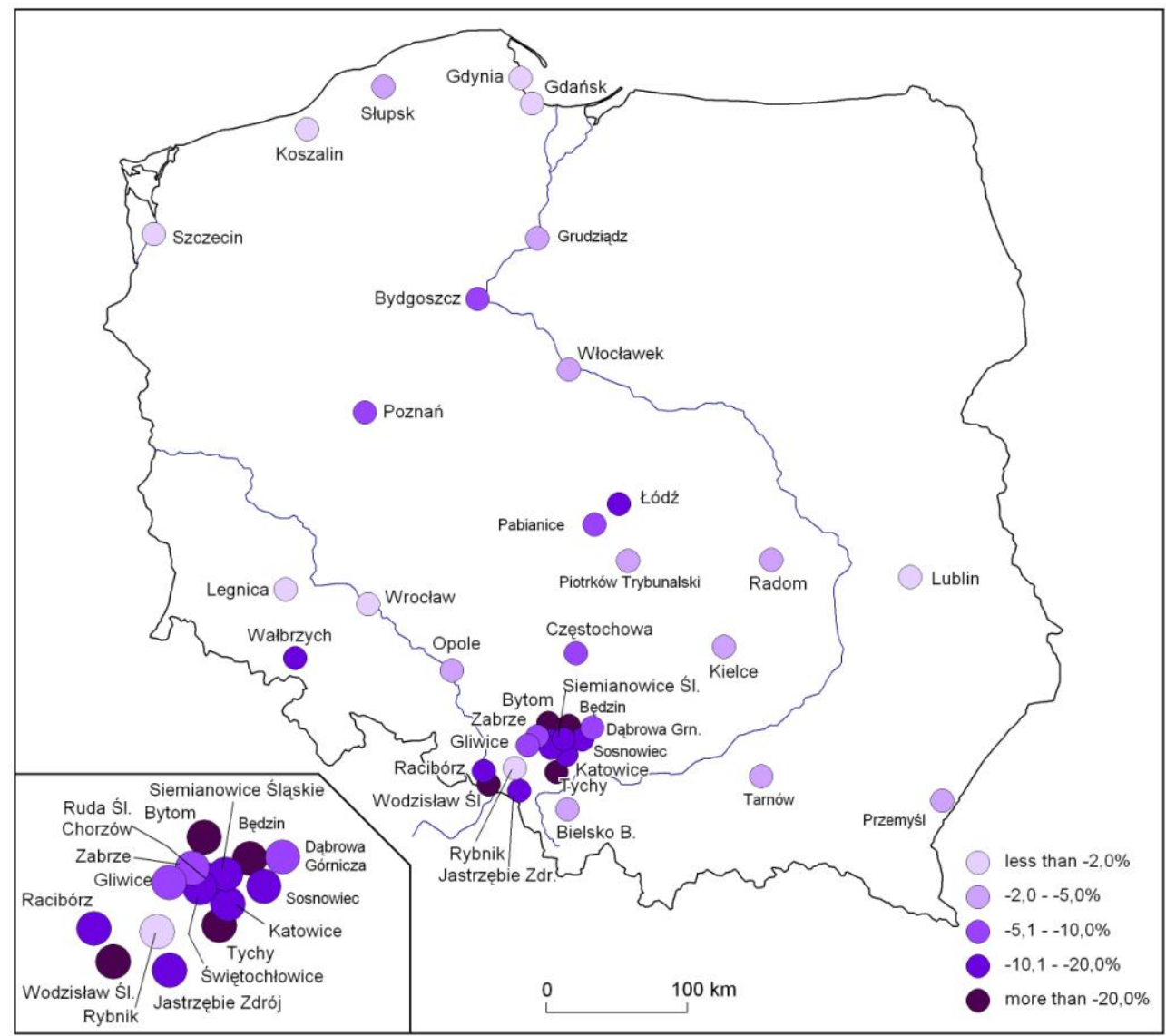

Fig. 3. Population decline of larger cities (more than 50000 inhabitants) in Poland, 1990-2010

All mono-central or bipolar agglomerations develop according to this model. The only exception is the Łódź agglomeration. It results from the fact that in the $19^{\text {th }}$ and $20^{\text {th }}$ centuries, industry was in a very high position in Łódź. Due to this fact, demographic development, and particularly the scale of depopulation in the last decades (a drop from 835 thousand in 1980 to 742 thousand in 2010), makes this centre similar to the cities located in the cores of post-industrial urban conurbations.

Exactly in such settlement types, we are most frequently dealing with actual depopulation. A population loss in the metropolitan core is accompanied by weak growth or a loss of population in the peripheral zone. It may be justified by the social, functional and economic situation. Not only does the central city become less attractive to live, but also almost all of its surroundings. The situation is worsened by the proximity of areas or metropolises, which are attractive in this respect (the Beskids, Kraków-Częstochowa Upland, Kraków or Wrocław).
The population of the core of the Katowice conurbation has dropped in the last 20 years by over 400 thousand inhabitants. According to the demographic prognosis of GUS (Central Statistical Office), it will drop by another 450 thousand in the period 2010-2030. In the previous period, the most severe population losses happened in Katowice (60 thousand), Bytom (50 thousand) and Sosnowiec (40 thousand) (RUnGE ET AL., 2011).

In the case of Bytom and several other large cities of the Silesian voivodeship, population decrease was partially brought about by the administrative breakdown of cities, due to which some of the hitherto districts have become administratively independent. A majority of them used to be towns, anyway. This phenomenon, except for the Silesian voivodeship, is not observed in Poland and simultaneously, is one of crucial symptoms of broadly understood city shrinkage (KRZYSZTOFIK \& SZMYTKIE, 2011). 


\section{Conclusions}

The depopulation problem of cities in Poland in the $20^{\text {th }}$ century and in the beginning of the $21^{\text {st }}$ century shall be examined in the context of rapid political, economic and social events, such as world wars, but also in the aspect of internal economic and political transformations at the break of the $20^{\text {th }}$ and the $21^{\text {st }}$ centuries.

Although war-related events brought about sudden population losses in the cities on the territory of Poland, the contemporary period after 1990, is evolutionary in this respect. In contrast to depopulation due to wars, it is difficult to estimate the term and the number value of actual drops. The GUS estimates suggest that generally, at least until 2030, almost all cites in Poland will be depopulating. Some of them will notice a stability in the population (Warsaw, Krakow). There is no data suggesting more significant increases of population. They can basically happen in the nearest time only and exclusively on the basis of the annexation of adjacent towns. Many cities would like to follow the footsteps of Rzeszów. Another phase of administrative development has already started in Warsaw (Wesoła) or Białystok. Strong tendencies are visible also in Lublin, Gliwice, Kraków or Wrocław.

Taking into account the functional aspect in demographic development, it shall be deemed that further development of services as the most important element of cities' economic base, is going to establish population drops in cities located in cores of large urban complexes, but is simultaneously going to lead to further growth of suburbanization. The indicated tendency to establish the model of the compact city, however desired, is at the moment in its initial phase in Poland. The stratification between the local and regional planning versus the reality of settlement and demographic processes are visible as well. Therefore, the general tendencies of population decrease in the majority of Polish cities shall be confirmed, however, as the factual circumstances of recent years have revealed, it might not be to the extent forecast by GUS.

\section{References}

Atlas Historyczny Świata. Państ. Przeds. Wyd. Kartogr., Warszawa-Wrocław, 1986.

Bernt M., Cortese C., Couch C., Cocks M., Grossmann K., Haase A., Krzysztofik R. 2014. How does(n't) urban shrinkage get onto the agenda? Experiences from Leipzig, Liverpool, Genoa, and Bytom. Int. J. for Urban and Regional Research, 38,5: 1749-1766.
Couch C., Cocks M., Bernt M., Grossmann K., Haase A., Rink D. 2012. Shrinking cities in Europe. Town \& Country Plan., June 2012: 264-270.

Długosz Z. 2005. Population movements in large Polish cities in 1988-2002. Bul. of Geogr., Socio-econ., Ser., 4: 25-36.

Gawryszewski A. 2005. Ludność Polski w XX wieku. Inst. Geogr. i Przestrz. Zagosp. PAN, Warszawa.

Haase A., Bernt M., Grossmann K., Mykhnenko V., Rink D. 2013. The Concept of Urban Shrinkage. Environ. and Plan., A, 46: 1519-1534.

Jelonek A. 1956. Liczba ludności miast i osiedli w Polsce $w$ latach 1810-1955. Dokum. Geogr., 5, IG i PZ PAN, Warszawa.

Jelonek A. 1967. Ludność miast i osiedli typu miejskiego na ziemiach Polski od 1810 do 1960 r. Dokum. Geogr., 3-4, IG i PZ PAN, Warszawa.

Kabisch N., Haase D., Haase A. 2012. Urban Population Development in Europe, 1991-2008: The Examples of Poland and the UK. Int. J. of Urban and Regional Research, 36, 6: 1326-1348.

Kantor-Pietraga I. 2014. Systematyka procesu depopulacji miast na obszarze Polski od XIX do XXI wieku. Wyd. Uniw. Śląski, Katowice.

Kantor-Pietraga I., Krzysztofik R. 2009. Rozwój demograficzny miast na obszarze województwa śląskiego od XIII do XXI wieku. WNoZ, Uniw. Śląski, Sosnowiec.

Krzysztofik R., Runge J., Kantor-Pietraga I. 2011. Paths of Shrinkage in the Katowice Conurbation. Case Studies of Bytom and Sosnowiec Cities. WNoZ, Uniw. Śląski, Sosnowiec.

Krzysztofik R., Runge A., Runge J., Kantor-Pietraga I. 2014. Miasta konurbacji katowickiej. [in:] Stryjakiewicz T. (ed.) Kurczenie się miast w Europie Środkowo-Wschodniej. Bogucki, Sci. Publ. House, Poznań: 89-101.

Krzysztofik R., Szmytkie R. 2011. Studia nad procesami $i$ strukturami osadniczymi sieci miast Polski Południowej. WNoZ, Uniw. Śląski, Sosnowiec.

Kurczenie się miast $w$ Europie Środkowo-Wschodniej. Stryjakiewicz T. (ed), Bogucki, Sci. Publ. House, Poznań, 2014.

Kurek S. 2005. Territorial Distribution of population change in Poland in the years 1991-2001. Bul. of Geogr., Socioecon. Ser., 4: 117-134.

Mykhnenko V., Turok I. 2008. East European Cities - Patterns of Growth and Decline, 1960-2005. Int. Plan. Stud., 13, 4: 311-342.

Powierzchnia i ludność $w$ przekroju terytorialnym oraz zmiany podziału administracyjnego. GUS, Warszawa, 1990.

Powierzchnia i ludność w przekroju terytorialnym w 2010 r. GUS, Warszawa, 2010.

Rink D., Couch C., Haase A., Krzysztofik R., Nadolu B., Rumpel P. 2014. The Governance of Urban Shrinkage in Cities in Central and Eastern Europe: Policies, Strategies and Instruments. Urban Research and Practice, 7, 3: 258-277.

Runge J., Kantor-Pietraga I., Krzysztofik R. 2011. Kurczenie się miast konurbacji katowickiej w świetle modelu urbanizacji. [in:] Wpływ mobilności zawodowej i migracji na rynek pracy miast i regionów, Dąbrowa Górnicza: 34-47.

Turok I., Mykhnenko V. 2007. The Trajectories of European Cities, 1960-2005. Cities, 24, 3: 165-182.

Wysiedlenia, wypędzenia i ucieczki. 1939-1959. Atlas ziem Polski. Sienkiewicz W, Hryciuk G. (eds.), Demart S.A., Warszawa, 2008. 